\title{
Remote and virtual laboratory as a modern instrument for induction of the pupils' inquiry activities with emphasis on the technical and science-based subjects
}

\author{
Jiří Dostál ${ }^{1}$ \\ ${ }^{1}$ Palacký University, Faculty of Education
}

\begin{abstract}
The inquiry-based instruction can be, based on results of many researches and investigations, considered as beneficial and perspective, regarding mainly the current social needs. It is at the most desirable to educate individuals who are creative, able to solve problems and discover unusual solutions. We react on the mentioned facts in this article by an implementation of modern technologies into a concept of the inquiry-based instruction. We work specifically on aspects bound to the remote and virtual laboratories.

The aim of the theoretical study is to specify application possibilities of the remote and virtual laboratories into the framework of the inquiry-based instruction. There were used theoretical research methods, mainly analysis, synthesis, deduction and induction. It is obvious from the obtained results that the remote and virtual laboratories are beneficial even despite the shortcomings, and, they are fully applicable in the framework of the inquiry-based instruction.
\end{abstract}

Keywords: remote laboratory, virtual laboratory, education, inquiry-based instruction

\section{Introduction}

The current social needs emphasize the education of an individual able to think creatively, not only to find problems but also to solve them effectively, to be cooperative, active, competitive, however, also tolerant and protecting the weaker ones. Even in the first grade of the basic school, the education should, by its active and practical nature and application of related methods, motivate pupils to study further, to lead them to a learning activity and cognition that it is possible to search for, discover, create and find a proper way to the problem solving.

The article focuses on the problem solving connected to the concept of instruction called the inquiry-based instruction in connection to the information technology, respectively, to the remote and virtual laboratories. We react on the education tendencies observable in the international context which manifest themselves in application of the nontraditional concepts of instruction not only at a level of basic school. The main purpose of this approach is to em- phasize the development and forming of the pupils' dispositions, i.a. cognition, thinking and imagination. The requirement of the pupil's development of competence to solve problems became important, as it is closely related to the inquiry-based instruction. These competences are often seen as unbound to the particular subjects, as the more general competences that are, however, applied in the concrete activities. The importance of the competence development was also noticed by Lesh and Zawojewski (2007, p. 764). They state that a highly developed problem-solving skill facilitates a further education and a successful integration into the society, but it is also necessary for a lot of personal activities. People have to often apply the knowledge, which they have learnt, in new situations and for that they need to control their basic thought and other general cognitive skills which create the essence of the individual competence for the problem solving.

\section{Remote laboratory}

The current technologies allow to realize the inquiry-based instruction even without a direct use of physical devices. There is not even a need of temporal nor regional bond, therefore a pupil can inquire anywhere and anytime (Dostál, 2013). There exists a number of varieties for this concept of research, e.g. author U. Harms (2000) considers 5 different varieties, but, from a practical point of view, it is desirable to differentiate only a remote laboratory (or a remotely controlled laboratory) and a virtual laboratory. The others are more or less varieties of those two given. During the inquiry with help of the remote laboratories, the obtained results are real because they are obtained on a real device.

Recently, the remote internet laboratories grow in importance. It is obvious on the image no. 1 that they are based on the fact that the real experiment is realised apart of the studying individual who controls it via the web interface through the computer network, they experiments and measures the relevant data. The experiments are not bound to a particular subject, therefore, there can be a chemical, physical, technical, or other type of experiment

The remotely controlled experiments have a number of advantages comparing to the classic school experiments in the traditional school laboratories or the virtual experiments (Látal, 2009): 
- the pupils can perform experiments from any place and in any time, they are not limited to perform it in their lessons,

- the experiment is ready anytime and set to measure, therefore there is no problem with lengthy and sometime difficult installation process,

- some of the experiments have their specifics for the given measured place (e.g. the calculation of the gravitational acceleration $g$ that can be calculated from a time of oscillation of the mathematical pendulum, is not a constant but it depends on i.a. the latitude of the place of measurement). The pupils have an opportunity to compare the results of the remote laboratories with their own experiments that they perform in the school laboratories,

- because of the security reasons, it is not possible to perform dangerous experiments in the classic school laboratories. In the remotely controlled laboratories, this danger (for the experimenter) is absent,

- comparing to the virtual simulations work, the pupils work with the real measuring aids and tools.

The disadvantage is however the dependence on the technical devices that work in a different rate of reliability and are energetically bound, e.g. in case of the electricity failure, the instruction cannot be performed.

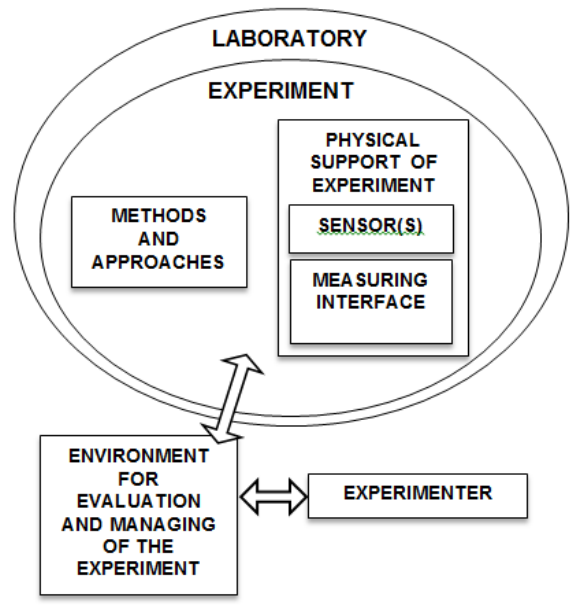

Fig. 1: Remote laboratory - principle

\section{Virtual laboratory}

The virtual laboratory functions almost without any technical support related to the inquiry, there is used only a computer for virtualisation of the inquiry process. This type of laboratory allows to realise a computer modelling and simulations while the user can interactively change the parameters of the studied phenomena and work with the data that they cannot really discover (cf. Jenisová, 2011). The whole experiment is programmed and the pupil can actively interfere in the programme's process. They influences the variables and then obtains the result. The virtual laboratory is schematically represented on the image no. 2 .

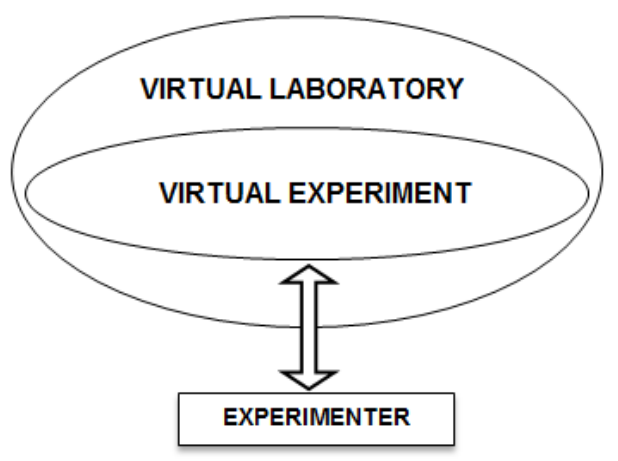

Fig. 2: Virtual laboratory - principle

The researches of the instruction supported by the virtual or remote experiments are not common in the Czech Republic. The exception can be a smaller (in terms of a range) research probe by F. Látal (2011). Its conclusions prove that the frequencies of the physics experiments in the instruction at the high schools are often very low and the use of the internet during the instruction is not a common phenomenon. 92 per cent of pupils also stated that they have never worked out remotely controlled experiments in their physics lessons at high school. However, as we can conclude from another question, the students would appreciate this kind of experiments. It should not be, however, the aim to replace the classic school experiments by the remotely controlled ones.

\section{Results and discussion}

There are studies evidencing the advantages of the virtual laboratories, e.g. M. Y. Morozov, A. Tanakov, A. Gerasimov, D. Bystrov and E. Cvirco (2004) state that the virtual laboratories and the simulations are powerful tools for active learning of pupils. These opinions have to be considered reluctantly, while the following analogy can be mentioned: we all feel the difference in the pupils' learning when they are visiting a real zoo and when they visit a virtual zoo (or when they simple observe the animals via the online camera). For the needs of learning, the non-mediated experiences stay hardly substitutable, and it should not be, if it is possible, replaced with the aim to make the realization of the instruction easier - which would not bring longterm effects. Even though many remote and virtual laboratories allow an interactive interference into the studied phenomena, they still remain merely a replacement.

In a similar sense, Z. Nedic, J. Machotka and A. Nafalski (2003) pointed out the efficiency of the virtual and remote experiments, which are, from the educational point of view, during the knowledge and skills development not such effective as the experiments realized in the real laboratories. 
In case that the inquiry-based activities of the pupils cannot be performed in real laboratories, the virtual and remote varieties play a hardly substitutable role during the application of the inquiry-based instruction. In this relation, Alexiou, Bouras and Ginnaka (2005) emphasize the economy of the use of the virtual laboratories during the instruction, and they state that the schools cannot afford all devices for the real experiments.

The experiences of the authors B. Dalgarno, A. G. Bishop, W. Adlong and D. R. Bedgoo (2009), based on the performed experimental study, show that the distant education at the university is appropriate for the use of the virtual laboratories as students evaluate it positively. They state that it is a valuable device for the knowledge development and recommend it for a further use. Lustigová, Mechlová, Malčík and Lustig (2009) notice that the interaction of the students is supported by the dynamical simulations of the real phenomena, team work (real and virtual), public presentations and defence of the obtained results; everything is happening either in the real presence, or online. The possibility of connecting the real phenomenon with the computer itself allows to get a better insight into the essence of the demonstrated phenomenon and obtaining of broader data range about the observed phenomenon (Lepil, 2010).

\section{Conclusion}

The experiment represents one of the possibilities how to change an instruction of the transmissive character into an instruction where the pupils can discover the cognition themselves and the teacher is only a guide on their way to cognition. A significant role in this is played by the teacher themselves who has to have appropriate competences for all of that. They has to be able to create situations where the pupils will feel the meaningfulness of the learning activities internally. Apart from that, it seems to be efficient to use modern information technologies as a support to the pupils' experimenting.

It can be assumed that in the future will be the tendency to apply the inquiry-based instruction growing and the pedagogic theory, including the field didactics, should react on this reality by researching the preconditions, conditions and results of its realization.

\section{References}

[1] Alexiou, A., Bouras, Ch., Giannaka, E. Virtual Laboratories in Education. Technology Enhanced Learning. Volume 171, p. 19 - 28. 2005.

[2] Dalgarno, A. B., Bishop, A. G., Adlong, W., Bedgoo, D. R. Effectiveness of a Virtual Laboratory as a preparatory resource for Distance Education chemistry students. Computers \& Education. Volume 53, Issue 3, p. $853-865.2009$.

[3] Dostál, J. Badatelsky orientovaná výuka jako trend soudobého vzdělávání. e-Pedagogium. Issue 3. s. 81 93. 2013.

[4] Harms, U. Virtual and remote labs in physics education. Second European Conference on Physics Teaching in Engineering Education. Budapest, Hungary, p. 140 - 146. 2000.

[5] Jenisová, Z. Vzdialené a virtuálne laboratoria. In Hašková, A. Pisoňová, M. Bitnerová, M. a kol. Didaktické prostriedky jako optimalizačný faktor procesu vzdelávania. Hradec Králové: Gaudeamus, s. 263 259. 2011.

[6] Látal, F. Porovnání charakteristik klasické a úsporné žárovky s využitím vzdáleně ovládané laboratoře. In Veletrh nápadů učiteli̊ fyziky. s. 147 - 151. 2009.

[7] Lepil, O. Teorie a praxe tvorby výukových materiálio. Olomouc: UP, 97. s. 2010.

[8] Lesh, Richard a Judith S. Zawojewski Problem solving and modeling. In: The Handbook of Research on Mathematics Teaching and Learning (2nd ed.): a Project of the National Council of Teachers of Mathematics. Editor Frank K. Lester. Reston, Virginia: Information Age Publishing, Charlotte, North Carolina, s. 763 - 804. 2007.

[9] Lustigová, Z., Mechlová, E., Malčík, M., Lustig, F. A new e-learning strategy for cognition of the real world in teaching and learning Science. The New Educational Review. roč. 17, sv. vol. 17, s. 305 - 318. 2009.

[10] Morozov, M. Y., Tanakov, A., Gerasimov, A., Bystrov, D., Cvirco, E. Virtual chemistry laboratory for school education. Advanced Learning Technologies. p. 605 - 608. 2004.

[11] Nedic, Z., Machotka, J. Nafalski, A. Remote laboratories versus virtual and real laboratories. Frontiers in Education. FIE 2003 33rd Annual. p. 31 - 36. 2003. 